\title{
Formaldehyde conductometric biosensor based on the recombinant formaldehyde dehydrogenase from the yeast Hansenula polymorpha
}

\author{
Olga F. Sosovska ${ }^{1}$, Halyna M. Pavlishko², Solomiya Ya. Paryzhak², Mykhailo V. \\ Gonchar $^{2}$, Yaroslav I. Korpan ${ }^{1}$ \\ ${ }^{1}$ Institute of Molecular Biology and Genetics, National Academy of Sciences of Ukraine, 150, Zabolotnogo Str., UA-03143, Kyiv-143, \\ Ukraine; \\ ${ }^{2}$ Institute of Cell Biology, National Academy of Sciences of Ukraine, 14/16 Drahomanov Str., 79005 Lviv, Ukraine \\ yakorpan@yahoo.com
}

\begin{abstract}
Gold interdigitated planar electrodes and $\mathrm{NAD}^{+}$- and glutathione-dependent formaldehyde dehydrogenase, isolated from the recombinant strain Tf 11-6 of the thermotolerant yeast Hansenula polymorpha, were used for development of conductometric biosensor sensitive to formaldehyde. New approach was proposed for preparing the sensor's bioelement, which includes immobilisation of low-molecular cofactors $\left(N_{A} D^{+}\right.$and glutathione) in bioselective layer to permit multiple assays without addition of the co-factors to an analyzed sample. Dependence of the biosensor's response on analyte concentration, $p H$ value and buffer concentration was investigated using model samples. The selectivity, operational and storage stabilities of the sensor developed were studied. A linear detection range for formaldehyde was shown to be 1-100 $\mathrm{mM}$.
\end{abstract}

Keywords: conductometric biosensor, Hansenula polymorpha, $\mathrm{NAD}^{+}$- and glutathione-dependent formaldehyde dehydrogenase, formaldehyde

Introduction. Nowadays the importance of constant monitoring of environmental conditions, quality of food products, and diagnostics of various diseases is indisputable. Therefore, the problem of development of novel promising techniques to analyse xenobiotics, toxic components of food products, and key metabolic elements becomes timely [1].

Formaldehyde is one of those insufficiently studied pollutants, which attract attention of many scientists [2]. It is widely used to synthesize tars in woodworking industry, in the production of detergents, lubricants, oil

(C) O. F. SOSOVSKA, H.M. PAVLISHKO, S.Ya. PARYZHAK, M.V. GONCHAR, Ya.I. KORPAN, 2008 products, in cosmetic, and textile industries. The application of formaldehyde in medicine is to disinfect and eliminate pathogens; it is also used in medical tools [3]. Annually around 10 million tons of formaldehyde are produced worldwide [4].

In everyday practice formaldehyde is detected by colorimetric methods, introduced in the beginning of the $20^{\text {th }}$ century. The majority of these methods are not selective, moreover, both reagents and products of the reaction are as harmful to the environment as formaldehyde itself. Some spectral methods - highly effective fluid chromatography, gas chromatography, fluorometry - require the application of toxic agents for 
derivatization of formaldehyde, and are performed in laboratories with high cost equipment by highly skilled personnel [5]. Besides, the aforementioned methods are inapplicable for express analysis as derivatization of analyte, installation of equipment, and analysis proper are very time-consuming. Thus, novel analytic achievements are aimed at the development of biosensor approach for the detection of formaldehyde contents in various samples. Laboratory prototypes of amperometric [6, 7], conductometric [9, 10], and piezoelectric biosensors as well as those based on enzymes and DNA-protein interactions [11] have been developed for detection of formaldehyde in different environmental conditions. However, neither of these prototypes has been introduced into manufacturing due to the series of disadvantages and structural complexity of the transductors.

The current work presents a conductometric biosensor, based on glutathione-dependent formaldehyde dehydrogenase (FDH), isolated from cells of recombinant strain Tf 11-6 of thermotolerant yeast Hansenula polymorpha, capable of producing surplus of this enzyme. Unlike other available commercial FDH preparations, i.e. bacterial Pseudomonas putida and yeast - Candida boidinii, the recombinant enzyme obtained is of higher specific activity and is more temperature tolerant [12].

Materials and Methods. Glutathione-dependent FDH (EC 1.2.1.1), isolated from recombinant strain Tf 11-6 of thermotolerant yeast Hansenula polymorpha, capable to produce surplus of this enzyme was used in our work [13]. The enzyme with specific activity 17 $\mathrm{U} / \mathrm{mg}$ was isolated using the method described in [12]. Formaldehyde was obtained by hydrolysis of paraform (Sigma-Aldrich Chemie, France), DEAE-dextran (Fluka Biochemica, France), 5\% alcohol solution of Nafion (Sigma-Aldrich Chemie, France). To immobilise the enzymes $50 \%$ aqueous solution of glutaric aldehyde (Serva, Germany) was used; bovine serum albumin (BSA) (fraction V) (Serva) was used to stabilise bioselective membranes with FDH. All the other chemicals were of analytical grade and were used without any additional treatment.

Conductometric set-up, described by A. A. Shulga et al., was used in our experiments [14]. Conductometric transducers were produced at the
Lashkarev Institute of Semi-Conductors Physics, National Academy of Sciences of Ukraine. The transducers consist of two identical pairs of golden interdigitated electrodes, produced by vacuum deposition of gold on pyroceramic substrate $(5 \times 40$ $\mathrm{mm})$. The size of sensitive surface of each of the electrode pairs was $1.0 \times 1.5 \mathrm{~mm}$. The distance between the digits and the width of digits were $20 \mu \mathrm{m}$ [15].

The following procedure was used to produce bioselective membranes: $0.2 \mathrm{MNAD}^{+}$solution in $0.2 \mathrm{M}$ K-phosphate buffer solution, $\mathrm{pH} 7.25$, was prepared and neutralized by concentrated $\mathrm{NaOH}$ to $\mathrm{pH}$ 7.2. To prepare bioselective membranes the mixture, containing $20 \mu \mathrm{l}$ of $\mathrm{NAD}^{+}$solution, $16 \mu \mathrm{l}$ of FDH solution with specific activity of $90 \mathrm{U} / \mathrm{ml}$, stabilized by ammonium sulfate, $2 \mathrm{mg}$ BSA, $2 \mathrm{mg}$ DEAE-dextran, and $4 \mu \mathrm{l}$ of $0.2 \mathrm{M}$ of neutralized glutathione solution, was prepared. The output solution for the referent membrane was prepared in the same way as for the bioselective membrane, but instead of aliquot of enzymatic solution $16 \mu \mathrm{l}$ of $20 \mathrm{mM}$ of phosphate buffer solution, $\mathrm{pH} 7.5$, were added. Each of the output solutions were dropped on the corresponding (measuring or referent) interdigitated electrode of conductometric transducer, which was then sustained for $25 \mathrm{~min}$ in the atmosphere of saturated vapors of glutaric aldehyde at $25^{\circ} \mathrm{C}$. The chip with bioselective and referent membranes was dried at room temperature for $15 \mathrm{~min}$, washed with $10 \mathrm{mM}$ borate buffer, $\mathrm{pH} 8.7$, for 24 hours at $4^{\circ} \mathrm{C}$ and then used in further experiments. We also experimented with stabilization of biomatrix with additional nafion membrane. In this case we did not add DEAE-dextran to the membrane, but formed additional membrane on the surface after immobilization in glutaric aldehyde vapors $[16,17]$.

The measurements were performed in the day light at room temperature $\left(20^{\circ} \mathrm{C}\right)$ in glass cell. A biosensor was immerged into a vigorously stirred sample solution, $2 \mathrm{ml}$ of $10 \mathrm{mM}$ borate buffer solution, $\mathrm{pH}$ 8.9. After baseline stabilization, formaldehyde was added to the vessel, and the differential output signal between the measuring and reference sensitive elements was registered with the experimental set-up described above. The steady state or kinetic response of the conductometric biosensor was plotted as a function of the formaldehyde concentration. 


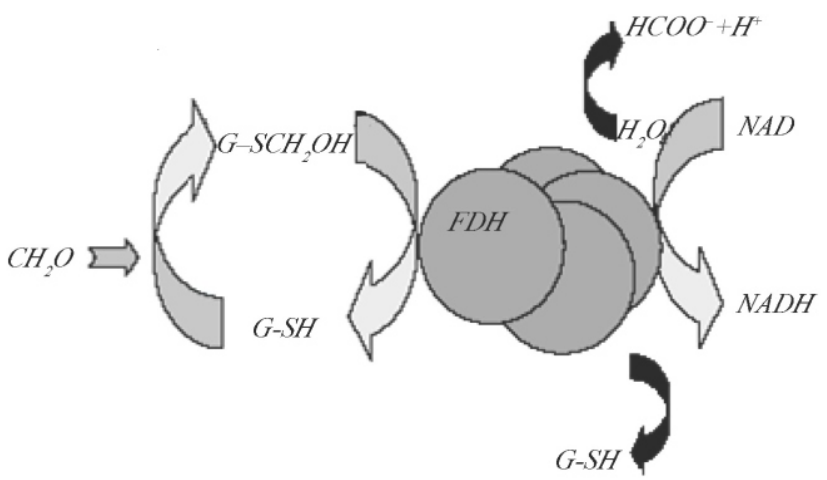

Fig.1 Scheme of enzymatic reaction with formaldehyde dehydrogenase

Results and Discussion. The operation of formaldehyde biosensor, based on glutathione-dependent $\mathrm{FDH}$, is based on a reaction producing ions - formic acid, which is dissociated to formate-anion and proton. This process determines the increase in electroconductivity of the analyte near the electrode surface, which is registered with a method of conductometric analysis (Fig.1).

We have used a new approach for formation of a bioselective element on the surface of thin-layer planar electrodes, which includes co-immobilisation of FDH with its co-factors $-\mathrm{NAD}^{+}$and glutathione. The introduction of DEAE-dextran to the biosensitive layer and additional covering with nafion membrane prevent the washing out of low-molecular co-factors from biomatrix, which allows developing a reagentless biosensor of multiple use, which does not require the introduction of FDH co-factors to the analysed solution. Securing the co-factors in the bioselective layer is achieved by the electrostatic interaction between positively charged DEAE-dextran and negatively charged phosphate groups $\mathrm{NAD}^{+}$and carboxylate groups of glutathione, as well as by putting the ionic barrier by negatively charged sulphate groups of nafion membrane. Besides, a high concentration of $\mathrm{NAD}^{+}$in the bioselective membrane $(\sim 100 \mathrm{mM})$ eliminates the need for an additional enzymatic system of $\mathrm{NAD}^{+}$regeneration. It is noteworthy that the majority of former FDH biosensors were based on covalent binding of $\mathrm{NAD}^{+}$, which decreased the accessibility and effectiveness of enzyme-substrate interactions significantly.

To define the optimal conditions of functioning of $\mathrm{FDH}$, immobilised in vapours of glutaric aldehyde, the dependences of the biosensor responses to formaldehyde on $\mathrm{pH}$ value, concentration of buffer solution, and ionic force of the solution have been studied.

Optimal $\mathrm{pH}$ value for functioning of native $H$. polymorpha FDH is known to be approximately 8.3 [5]. The experiments with enzyme, immobilised in vapours of glutaric aldehyde, showed insignificant shift on $\mathrm{pH}$-optimum towards the alkaline region, as the highest values of responses to the introduction of substrate were registered at $\sim \mathrm{pH} 8.9$ (Fig.2). Slight change in $\mathrm{pH}$-optimum for $\mathrm{FDH}$, immobilised on the surface of conductometric transducers, may be determined by both insignificant conformation change of the enzyme while interacting with glutaric aldehyde molecules and specificity of interaction of ionic groups of DEAE-dextran, albumin, and FDH co-factors with the buffer system components.

The conductometric method is based on the measuring of changes in an analyte conductivity dependent on the course of enzymatic reaction and the features of working buffer solution. Taking into account the aforementioned facts, we have studied the dependence of the biosensor response on

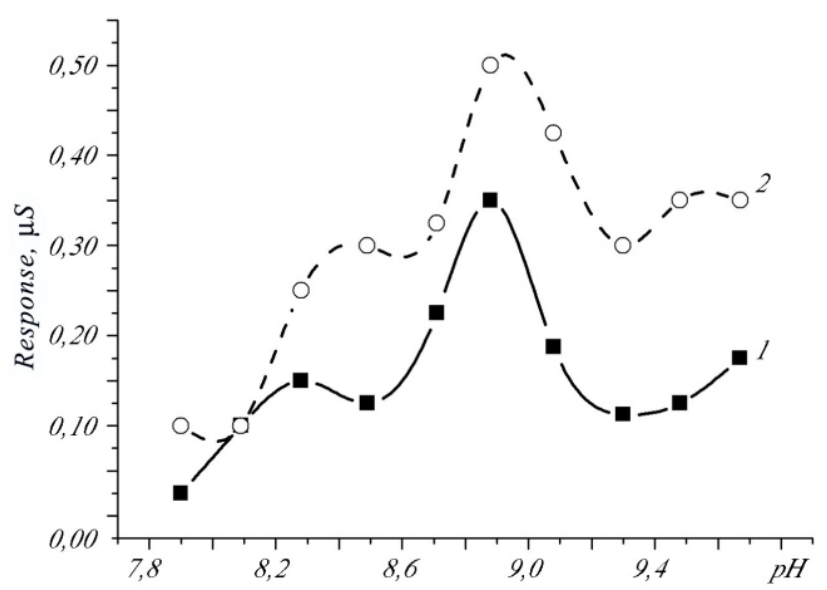

Fig.2 Dependence of FDH-based biosensor response on $\mathrm{pH}$ value of $10 \mathrm{mM}$ working borate buffer with 5 (1) and 10 (2) $\mathrm{mM}$ of formaldehyde; for this experiment bioselective membrane was formed with DEAE-dextran 


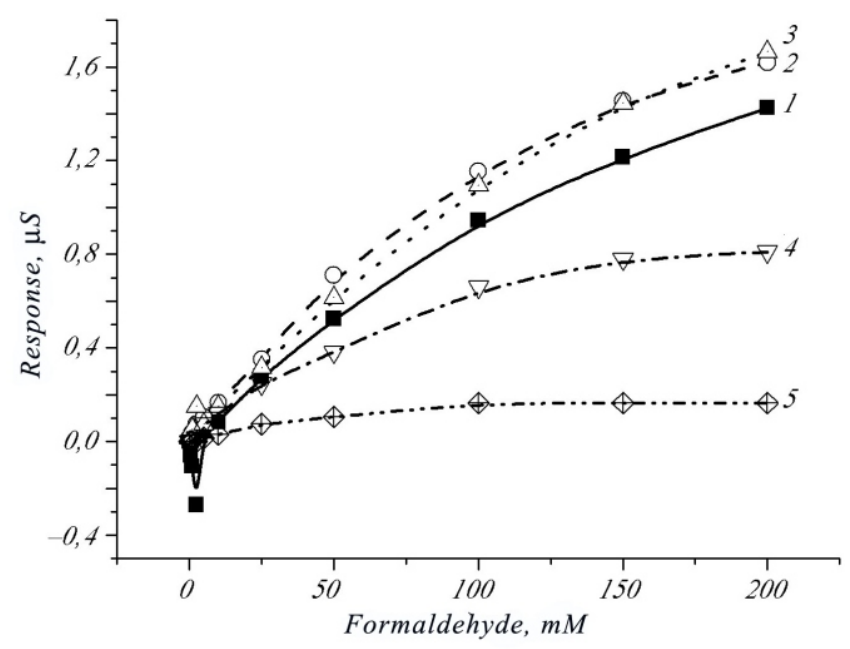

Fig.3 Dependence of FDH-based biosensor response on formaldehyde concentration with 5 (1), 10 (2), 15 (3), 25 (4), and 50 (5) $\mathrm{mM}$ borate buffer, $\mathrm{pH} 8.9$; for this experiment bioselective membrane was formed with DEAE-dextran

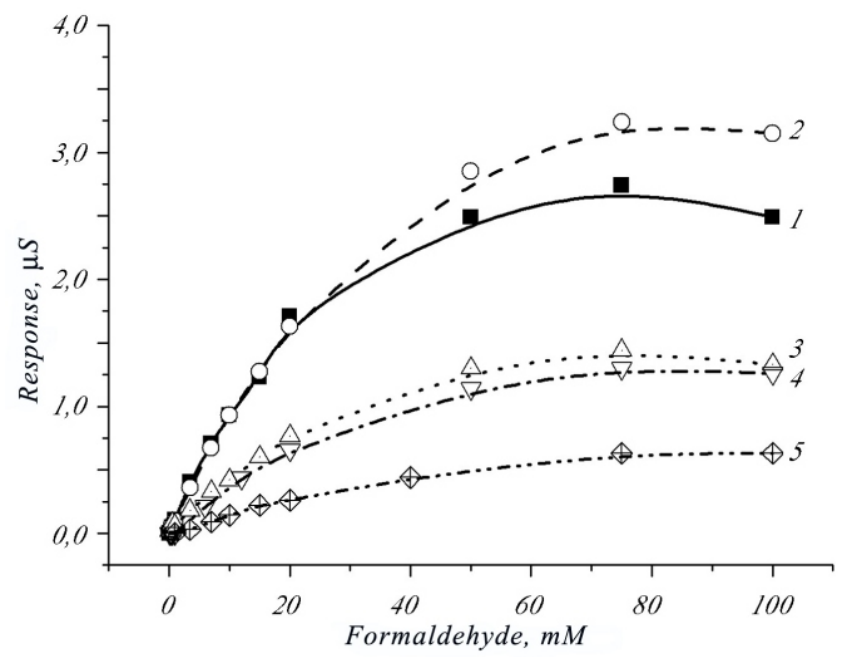

Fig.4 Dependence of FDH-based biosensor response on formaldehyde concentration with 5 (1), 10 (2), 15 (3), 25 (4), and 50 (5) $\mathrm{mM}$ borate buffer, $\mathrm{pH} 8.9$; additional nafion membrane was formed on the biosensor surface

concentrations of formaldehyde and buffer solution. Fig. 3 and 4 show that linear range of detection is $1-100$ and $1-50 \mathrm{mM}$ of formaldehyde for the biomatrix with DEAE-dextran and additional nafion membrane, respectively. The foreseen bottom threshold of the biosensor was $1 \mathrm{mM}$ of the analyte, however, it may be decreased via the increase in conductometer sensitivity. The optimal concentration of the working buffer for glutathione-dependent formaldehyde dehydrogenase, immobilised in the vapours of glutaric aldehyde, is 10 $\mathrm{mM}$. Such optimal value of the buffer solution may be explained by sufficient buffer capacity for operating of the enzyme and relatively low background conductivity. Therefore, the optimal condition for the conductometric biosensor, based on $H$. polymorpha $\mathrm{FDH}$, immobilised in vapours of glutaric aldehyde, is $10 \mathrm{mM}$ buffer solution with $\mathrm{pH}$ 8.9.

As it has been expected, the biosensor developed is highly selective to formaldehyde, the basic substrate (Fig.5). Other compounds, methanol and ethanol in particular, cause an insignificant shift in response of the conductometric biosensor. However, the presence of methanol and ethanol in samples may result in the increase of the biosensor response value towards formaldehyde. The latter fact may be explained by their ability to influence the dissociation of formic acid as a result of alteration of solution dielectric constant by alcohols.

Operational and storage stabilities are known to be among the most important features of any biosensor. To investigate the operational stability of the biosensor developed, we registered the response for two concentrations of formaldehyde, 10 and $25 \mathrm{mM}$, throughout the day with one hour interval. Fig. 6 shows highly reproducible response of the conductometric biosensor to each of the formaldehyde concentrations along with a standard deviation of the sensor response not exceeding $4 \%$. The best conditions in terms of storage stability (Fig.7) were obtained for the storage of the biosensor in $10 \mathrm{mM}$ borate buffer solution, $\mathrm{pH} 8.9$, $4^{\circ} \mathrm{C}$. The biosensor preserved the capacity of stable response in the course of at least 140 days.

Conclusions. The conductometric formaldehyde-sensitive biosensor, based on $\mathrm{NAD}^{+}$and glutathione-dependent formaldehyde dehydrogenase isolated from the recombinant strain Tf 11-6 of thermotolerant yeast Hansenula polymorpha, was developed. The gold interdigitated planar electrodes were used as transducers. The new approach for the preparation of bio-element, which includes the immobilisation of low-molecular co-factors $\left(\mathrm{NAD}^{+}\right.$and glutathione) in the bio-selective layer to allow multiple analysis without their introducing into an analysed sample, was proposed. The dependence of the biosensor response on the concentration of target 


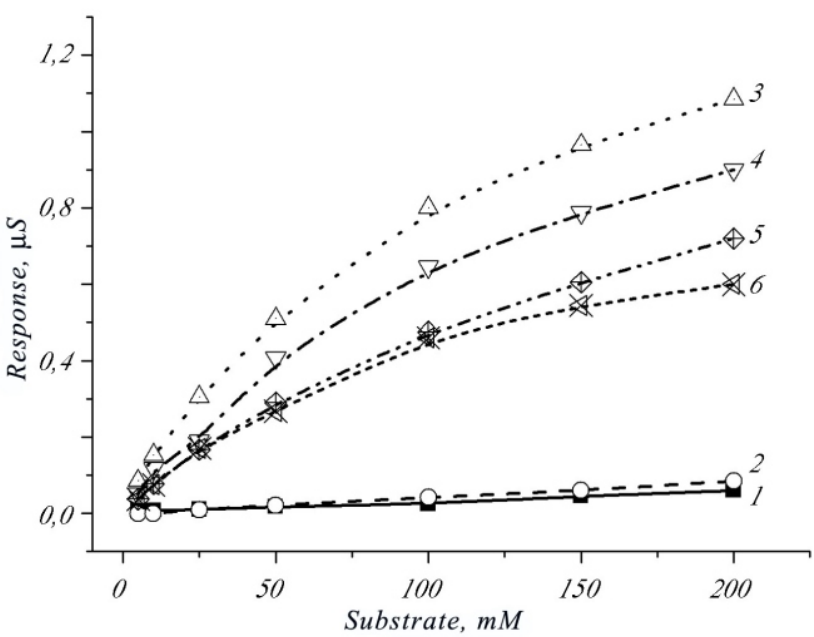

Fig.5 Dependence of response value of conductometric biosensor, based on FDH Hansenula polymorpha on the concentration of methanol (1), ethanol (2), formaldehyde (3), equimolar mixtures of formaldehyde and methanol (4), formaldehyde and ethanol (5), formaldehyde, methanol, and ethanol ( 6 ) in the measured solution; for this experiment bioselective membrane was formed with DEAE-dextran

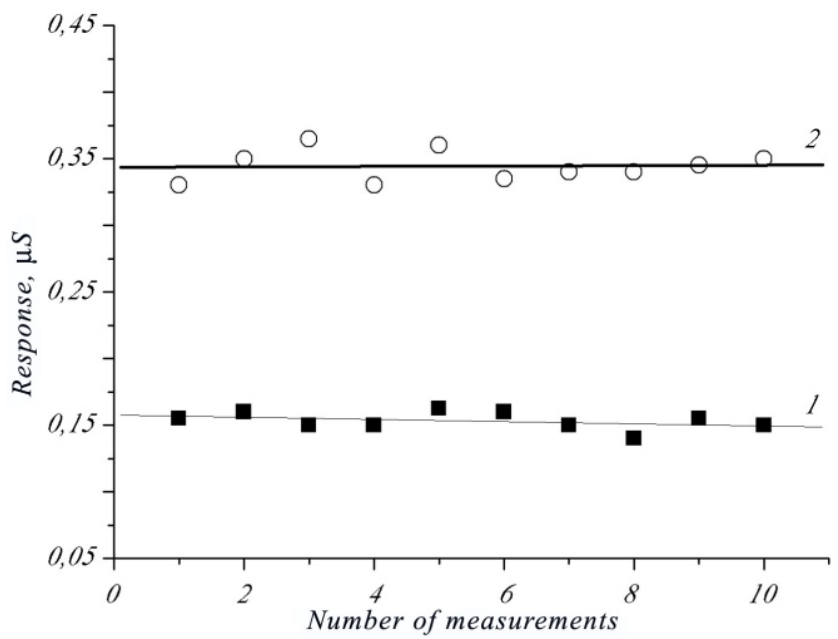

Fig.6 Reproducibility of biosensor response to $10 \mathrm{mM}$ (1) and 25 $\mathrm{mM}$ (2) formaldehyde; the measurements were carried out in $10 \mathrm{mM}$

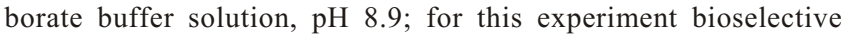
membrane was formed with DEAE-dextran

analyte, $\mathrm{pH}$, and buffer concentration was investigated. The operational and storage stabilities as well as selectivity of the biosensor were studied. In comparison with the biosensor based on commercially available bacterial formaldehyde dehydrogenase [10], the proposed conductometric biosensor revealed higher storage stability and better specificity. The

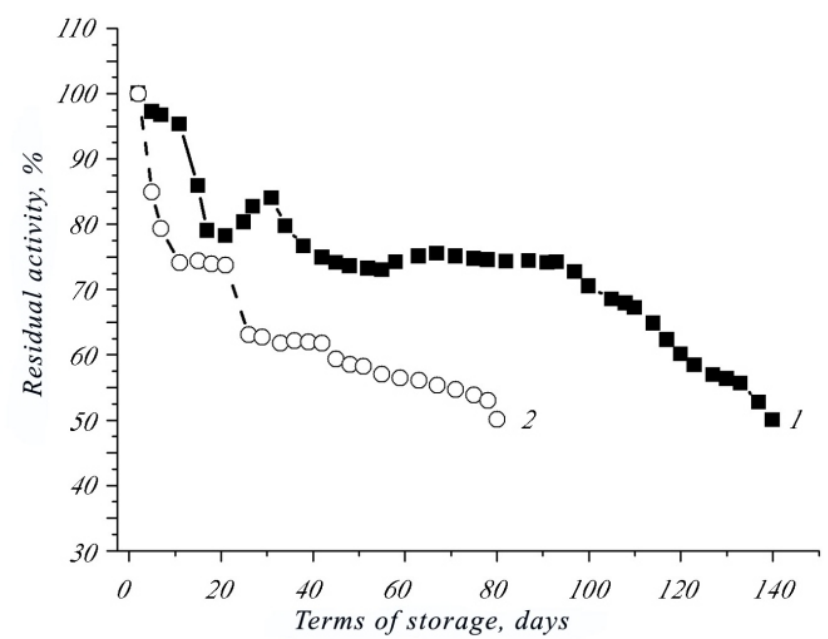

Fig.7 Stability of response biosensor, stored in $10 \mathrm{mM}$ borate buffer solution, $\mathrm{pH} 8.9$ (1) and after dry storage at $4{ }^{\circ} \mathrm{C}$ (2); for this experiment bioselective membrane was formed with DEAE-dextran

investigation of the proposed conductometric biosensors analytical performances in real samples, such as pharmaceuticals, waste waters, fish meat extracts and biological fluids, is in progress.

О. Ф. Сосовська, Г. М. Павлішко, С. Я. Парижак, М. В. Гончар, Я. I. Корпан

Формальдегідний кондуктометричний біосенсор на основі рекомбінантної формальдегіддегідрогенази дріжджів Hansenula polymorpha

Резюме

Для розробки кондуктометричного біосенсора, чутливого до формальдегіду, використано золоті гребінчасті планарні електроди та $\mathrm{NAD}^{+}$- $і$ глутатіон-залежну формальдегіддегідрогеназу, виділену з клітин рекомбінантного итаму Tf 11-6 термотолерантних дріжджів Н. polyтогрhа, здатних до надпродукування иъього ферменту. Запропоновано новий підхід до створення біоелемента сенсора, який включає іммобілізацію у біоселективному шарі низькомолекулярних кофакторів (NAD та глутатіону) і дозволяє проводити багаторазовий аналіз без їхнього внесення в зразок. Крім того, зникає необхідність у регенерації $\mathrm{NAD}^{+}$за рахунок його високої локальної концентрації в мембрані. Досліджено залежність величини сигналу біосенсора від кониентрації аналіту, величини рН та концентраціі буфера. Вивчено також операчійну стабільність, стабільність при зберіганні та селективність створеного біосенсора. Лінійний динамічний діапазон визначення концентраиії формальдегіду становить 1-100 мМ .

Ключові слова: кондуктометричний біосенсор, Hansenula polymorpha, $\mathrm{NAD}^{+}$- $i$ глутатіон-залежна формальдегіддегідрогеназа, формальдегід. 
О. Ф. Сосовская, Г. Н. Павлишко, С. Я. Парижак, М. В. Гончар, Я. И. Корпан

Формальдегидный кондуктометрический биосенсор на основе рекомбинантной формальдегиддегидрогеназы дрожжей Hansenula polymorpha

Резюме

Для разработки кондуктометрического биосенсора, чувствительного к формальдегиду, использованы золотые гребенчатые планарные электроды, $\mathrm{NAD}^{+}-\mathrm{u}$ глутатион-зависимую формальдегиддегидрогеназу, полученную из клеток рекомбинантного штамма Tf 11-6 термотолерантных дрожжей H. polymorpha, способных сверхпродуцировать этот фермент. Предложен новый подход к созданию биоэлемента сенсора, подразумеваюший иммобилизацию низкомолекулярных кофакторов (NAD ${ }^{+}$и глутатиона) в биоселективной матрице, что делает возможным проведение многократного анализа без их внесения в исследуемый образеи. Кроме того, исчезает необходимость регенерации $\mathrm{NAD}^{+}$за счет его высокой локальной кониентрачии в мембране. Изучена зависимость величины сигнала биосенсора от концентрации измеряемого вещества, величины рН и кониентрации буфера. Исследована также операционная стабильность, стабильность при хранении и селективность созданного биосенсора. Линейныци диапазон измерения концентрации формальдегида составляет $1-100 \mathrm{MM}$.

Ключевые слова: кондуктометрический биосенсор, Hansenula polymorpha, $\mathrm{NAD}^{+}-u$ глутатион-зависимая формальдегиддегидрогеназа, формальдегид.

\section{REFERENCES}

1. Nikitina O., Shleev S., Gayda G., Demkiv O., Gonchar M., Gorton L., Csoregi E., Nistor M. Bi-enzyme biosensor based on $\mathrm{NAD}^{+}$- and glutathione-dependent recombinant formaldehyde dehydrogenase and diaphorase for formaldehyde assay // Sensors and Actuators.-2007.-125.P. 1-9.

2. Kawamura K., Kerman K., Fujihara M., Nagatani N., Hashiba T., Tamiya E. Development of a novel hand-held formaldehyde gas sensor for the rapid detection of sick building syndrome // Sensors and Actuators.-2005.-105.P. 495-501.

3. Ngamchana S., Surareungchai $W$. Sub-millimolar determination of formalin by pulsed amperometric detection // Analyt. Chim. Acta.-2004.-510.-P. 195-201.

4. Herschkovitz Y., Eshkenazi I., Campbell C. E., Rishpon J. An electrochemical biosensor for formaldehyde // J. Electroanalyt. Chem.-2000.-491.-P. 182-187.

5. Сибирный В. А., Гончар М. В., Рябова О. Б., Майдан М. М. Современные методы анализа формальдегида, метанола и этанола // Мікробіол. журн.-2005.-67, № 4.-Р. 85-110.

6. Khlupova M., Kuznetsov B., Demkiv O., Gonchar M., Csoregi $E$., Shleev $S$. Intact and permeabilized cells of the yeast Hansenula polymorpha as bioselective elements for amperometric assay of formaldehyde // Talanta.2007.-71.-P. 934-940.

7. Kataky R., Bryce M. R., Goldenberg L., Hayes S., Nowak A. A biosensor for monitoring formaldehyde using a new lipophilic tetrathiafulvalene-tetracyanoquinodimethane salt and a polyurethane membrane // Talanta.-2002.-56.P. 451-458.

8. Korpan Y. I., Gonchar M. V., Sibirny A. A., Martelet C., El'skaya A. V., Gibson T. D., Soldatkin A. P. Development of highly selective and stable potentiometric sensors for formaldehyde determination // Biosensors and Bioelectronics.-2000.-15.-P. 77-83.

9. Dzyadevych S. V., Arkhypova V. N., Korpan Y. I., El'skaya A. V., Soldatkin A. P., Jaffrezic-Renault N., Martelet $C$. Conductometric formaldehyde sensitive biosensor with specifically adapted analytical characteristics // Analyt. Chim. Acta.-2001.-445.-P. 47-55.

10. Солдаткін О. О., Сосовська.О. Ф., Бенілова І. В., Гончар M. В., Корпан Я. I. Новий кондуктометричний біосенсор для визначення концентрації формальдегіду у модельних зразках // Біополімери і клітина.-2005.-21, № 5.- Р. 425432.

11. Bunde R. L., Jarvi E. J., Rosentreter J. J. A piezoelectric method for monitoring formaldehyde induced crosslink formation between poly-lysine and poly-deoxyguanosine // Talanta.-2000.-51.-P. 159-171.

12. Demkiv O. M., Paryzhak S. Ya., Gayda G. Z., Sibirny V. A., Gonchar $M$. $V$. Formaldehyde dehydrogenase from recombinant yeast Hansenula polymorpha: isolation and bioanalytical application // FEMS Yeast Res.-2007.-7.P. 1153-1159.

13. Демків О. М., Парижак С. Я., Красовська О. С., Стасик О. В., Гайда Г. З., Сибірний А. А., Гончар М. В. Конструювання штамів - надпродуцентів формальдегіддегідрогенази метилотрофних дріжджів Hansenula polymorpha // Біополімери і клітина.-2005.-21, № 6.-P. 525-530.

14. Shul'ga A. A., Soldatkin A. P., El'skaya A. V., Dzyadevich S. V., Patskovsky S. V., Strikha V. I. Thin-film conductometric biosensors for glucose and urea determination // Biosensors and Bioelectronics.-1994.-9.-P. 217-223.

15. Arkhypova V. M., Bereghetskyy A. L., Shul'ga O. A., Chovelon J.-M., Soldatkin A. P., Dzyadevych S. $V$. Investigation and optimization of conductometric transducers based on planar technology // Sensor Electron. Microsystem Technol.-2005.-2.-P. 48-54.

16. Ben Ali M., Korpan Y., Gonchar M., El'skaya A., Maaref M. A., Jaffrezic-Renault $N$., Martelet $C$. Formaldehyde assay by capacitance versus voltage and impedance measurements using bi-layer bio-recognition membrane // Biosensors and Bioelectronics.-2006.-22.-P. 575-581.

17. Ben Ali M., Gonchar M., Gayda G., Paryzhak S., Maaref M. A., Jaffrezic-Renault $N$., Korpan Ya. Formaldehyde-sensitive sensor based on recombinant formaldehyde dehydrogenase using capacitance versus voltage measurements // Biosensors and Bioelectronics.-2007.-22.-P. 2790-2795.

UDC 577.150.87+543.8:547.262 Received 20.11.07 